\title{
Comparitive Analysis of Fuzzy Based MPPT for Boost and SEPIC Converter Topologies for PV Application
}

\author{
Rajeshree Patil ${ }^{1}$, Harsha Anantwar ${ }^{2}$ \\ ${ }^{I}$ (Electrical and Electronics,Dayananda Sagar College of Engineering, India) \\ ${ }^{2}$ (Electrical and Electronics,Dayananda Sagar college of Engineering, India)
}

\begin{abstract}
This paper proposes the Maximum Power Point Tracking based on Fuzzy logic control for PV System.MPPT is required to extract maximum power corresponding to specific operating point. The output power of PV System is depends on weather conditions i.e. solar irradiation and atmospheric temperature. In this work PV System model is implemented in MATLAB at different irradiation and constant atmospheric temperature with different converter topology such as Boost and SEPIC. A Fuzzy Logic control (FLC) based MPPT technique proposed here, shows improvement in the efficiency of a PV based energy system and further comparison is made between Boost and SEPIC Converter under variable atmospheric conditions and temperature to validate the results.
\end{abstract}

Keywords: PV Panel, SEPIC Converter, Fuzzy Logic Controller and MPPT.

\section{Introduction}

Non conventional type of energy sources are al so called type of renewable Energy sources which are continuously available from nature [1].The renewable energy comes from sun and wind, can never be depleted. Maximum power point tracking has been developed [2], in order to enhance the efficiency of PV system. There are many types of converter out of them most identified Power converters are the Buck Converter, the Boost converter and Buck-Boost converters. [3] [4].There are several techniques to control input voltage of DC Converter [5]. Among various control methods FLC is uncomplicated and simplest to be used with PV system. Recently, FLC can work with imprecise inputs, and does not necessitate little knowledge of the process to be controlled [6][7].

This paper aim to develop and simulate FLC MPPT for PV System and results are analyzed and compared with an FLC-based MPPT with Boost converter and Power comparison is made between Boost and SEPIC Converter and Efficiency of converters is determined under variable atmospheric temperature and Irradiation levels.

\section{Photovoltaic System}

A PV system is a power system designed to supply exploitable solar power by means of photovoltaic cell. The Solar Cell usually consists of shunt and series resistances. The resistance connected in parallel is very large and that of resistance connected in series is very small. Model of Photovoltaic Cell as shown in Fig.1 The equations of PV Systems are described as below

The Output current $\left(I_{p v}\right)$ of PV System can be expressed by

$I_{p v}=I_{p h}-I_{s} \times\left[\exp \left(\frac{q\left(V_{p v}+I_{p v} \times R_{s}\right)}{N_{S} A K T}\right)-1\right]-\frac{V_{p v}+I_{p v} \times R_{s}}{R_{S h}}$

The photocurrent $I_{p h}$ can be expreesed by

$I p v=I s c+(K i(T-T r e f)) \frac{G}{G r e f}$

The saturation current of diode is can be expressed by

$I s=\operatorname{Irs}\left(\frac{T}{T r \in f}\right)^{3}\left[\exp \left(\frac{q E g}{A k}\right) \times\left(\frac{1}{T r \theta f}\right)-\left(\frac{1}{T}\right)\right.$

The reverse saturation current $I_{r s}$ can be expressed by

$$
\text { IrS }=\frac{I s c}{\left(\exp \left(\frac{q \times V O C}{N s A K T}\right)-1\right)}
$$

Where:

$I_{p v}=$ PV Panel output Current

$V_{p v}=\mathrm{PV}$ Panel output voltage 
Voc $=$ PV Panel open Circuit voltage

$I_{s c}=\mathrm{PV}$ Panel short circuit current

$I p h=$ Photocurrent of PV Panel

Is $=$ Saturation Current of Diode

Irs = Reverse Saturation Current

Rs $=$ Resistance connected in Series

$R_{s h}=$ Resistance Connected in Parallel

$\mathrm{T}=$ Operating Temperature

Tref $=$ Reference Temperature (25 degree Celsius at STC)

$\mathrm{G}=$ Solar Irradiation

$G_{\text {ref }}=$ Reference Solar Irradiation

$\mathrm{A}=$ Ideality factor of diode $(\mathrm{A}=1.3$ for silicon diode $)$

$\mathrm{Ns}=$ Cells Connected in series

$N_{p}=$ Cells Connected in parallel

$E^{g}=$ Band gap energy of semiconductor $\left(E^{g}=1.1 \mathrm{eV}\right.$ for silicon)

Although there have been more model that use double diode model for better characteristics curves. But in this work single diode model is used because it offers a good balance between correctness and simplicity. Most of the parameters in the equations should be obtained from data sheet provided by manufactures. The PV panel specification of the proposed system as shown in Table I.

Table I. PV Cell Electrical Parameter

\begin{tabular}{|l|l|l|}
\hline Parameter & Variable & Value \\
\hline Maximum Power & $P_{\max }$ & $50 \mathrm{~W}$ \\
\hline Voltage at MPP & $V_{\operatorname{mav}}$ & $18.0 \mathrm{~V}$ \\
\hline Current at MPP & $I_{\operatorname{mg}}$ & $2.724 \mathrm{~A}$ \\
\hline O. C. Voltage & Voc & $22.94 \mathrm{~V}$ \\
\hline S. C. Current & $I_{x z}$ & $2.95 \mathrm{~A}$ \\
\hline Total cells in series & Ns & 36 \\
\hline
\end{tabular}

\section{Boost Converter And Sepic Converter}

Boost converter is a step up converter. It is a class of Switched mode power supply converter containing at least one uncontrolled switch and one controlled switch and for Ripple reduction purpose filters are connected to the output of the converter. The input-Output relationship for continuous conduction mode is given by

$$
V o=\frac{1}{1-D} V i
$$

The above relationship shows the output voltage is greater than the input voltage.

The output resistance of the converter Ro connected to the panel can be writtened according to Rpv as shown in below equation.

$$
R o=\frac{R p v}{(1-D)^{2}}
$$

Since the duty cycle is less than 1 , than the converter function as an elevator when the load Rs satisfy the following condition: Ro>Rpv

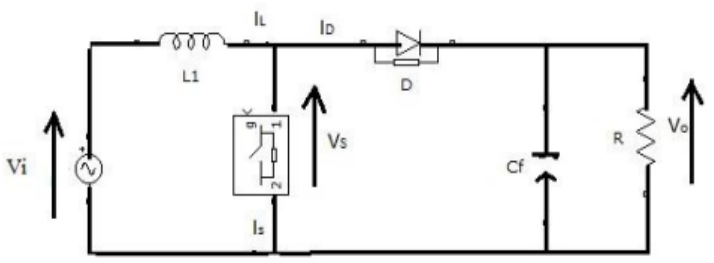

Fig.2. DC-DC Boost converter

The SEPIC Converter works in both buck and boost mode so that output voltage can be adjusted as per the requirement. It consists of inductors and capacitors, the values considered for inductors are very large and current in them are constant and the values considered for capacitors are very large and Voltage in them are constant. 
The input-output relationship for Continuous conduction mode is given by

$$
V o=V i \frac{D}{1-D}
$$

The above relationship shows that the output voltage is either high or lower than the input voltage. The output resistance of the converter Ro connected to the panel can be writtened according to Rpv as shown in below equation.

$R o=\operatorname{Rpv}\left(\frac{D}{1-D}\right)^{2}$

If $\mathrm{D}<0.5$ then the converter act as a step down

If $\mathrm{D}>0.5$ then the converter act as a step up

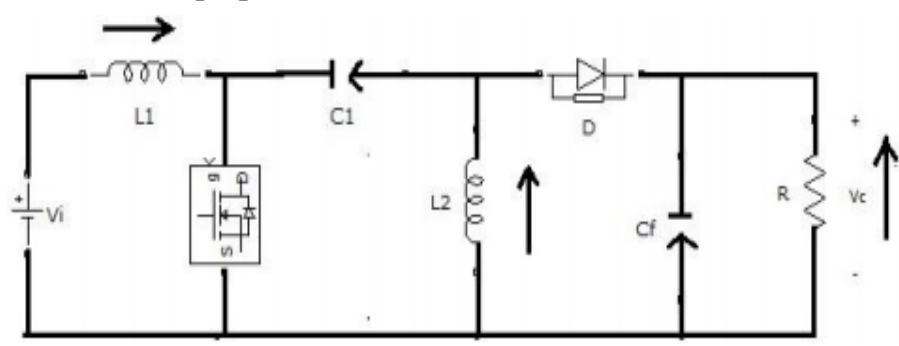

Fig.3. DC-DC SEPIC Converter

The current ripple is fixed to $10 \% \mathrm{I}_{\mathrm{L}}$ and Voltage ripple is fixed to $2 \% \mathrm{~V}_{\mathrm{O}}$

Table II. Specifications Of DC -DC Boost And Sepic Converter.

\begin{tabular}{|c|c|}
\hline BOOSTCONVERTER PARAMETERS & SEPICONVERTER PARAMETERS \\
\hline $\mathrm{L}=160 \mu \mathrm{H}$ & $\mathrm{L} 1=\mathrm{L} 2=67 \mu \mathrm{H}$ \\
\hline $\mathrm{C}=11 \mu \mathrm{F}$ & $\mathrm{C} 1=\mathrm{C} 2=27 \mu \mathrm{F}$ \\
\hline $\mathrm{R}=11.02 \Omega$ & $\mathrm{R}=4.15 \Omega$ \\
\hline $\mathrm{F}=1000 \mathrm{kHz}$ & $\mathrm{F}=100 \mathrm{kHz}$ \\
\hline
\end{tabular}

\section{Mppt Techniques}

There are numerous MPPT techniques have been developed and implemented by researchers. The MPPT techniques considered in this work is based on Fuzzy logic control.

The implementation of FLC is to extract maximum power by reducing the voltage oscillation.FLC operation comprises fuzzification, inference engine and defuzzification as shown in Fig.4.The inputs for FLC selected in this work are deviation of Power (dPpv) and deviation of Voltage (dVpv) at sample time $\mathrm{N}$ from the solar cell while the output of FLC is Duty Cycle to generate error signal E (N) which are represented by equation (9) and change in error signal in equation (10).The two input variables are described by,

$E(N)=\frac{P p v(N)-P p v(N-1)}{V p v(N)-V p v(N-1)}$

$$
d E(N)=E(N)-E(N-1)
$$

(10)

Where, $\operatorname{Vpv}(\mathrm{N})$ and $V p v(N)$ are the power and voltage from the PV Module.

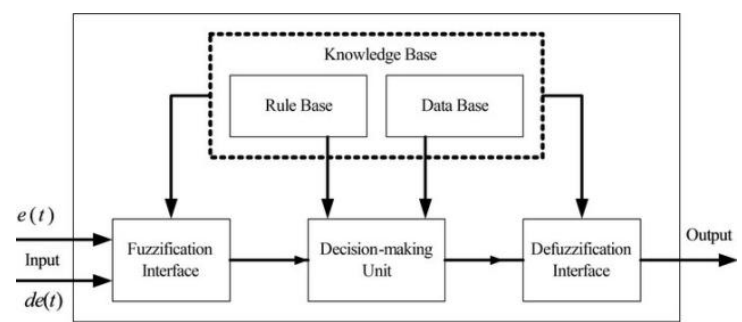

Fig.4.Main components in Fuzzy Logic controller

\section{A) Fuzzification Interface}

Membership Functions Selected for FLC are triangular type, due to its simplicity. For the input Membership functions(MF) five linguistic variables are selected as, H(Very High), H(High), Medium(M), L(Low) and VL(Very Low). The fuzzy subset separation and the membership function shape, which can adjust 
shape up to approximate system for input $\mathrm{dPpv}$ is as shown in Fig.5. And another input $\mathrm{dVpv}$ is as shown in Fig.6. The Output $D$ is as illustrated in Fig.7

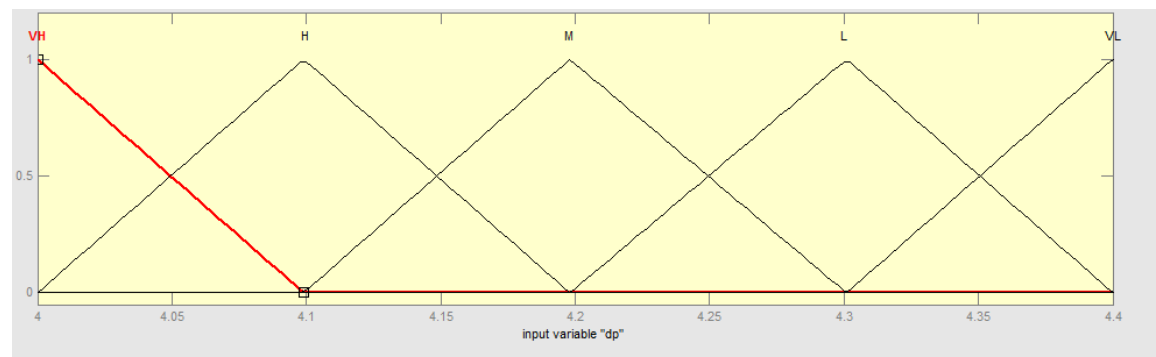

Fig.5.Input (dPpv) Membership functions

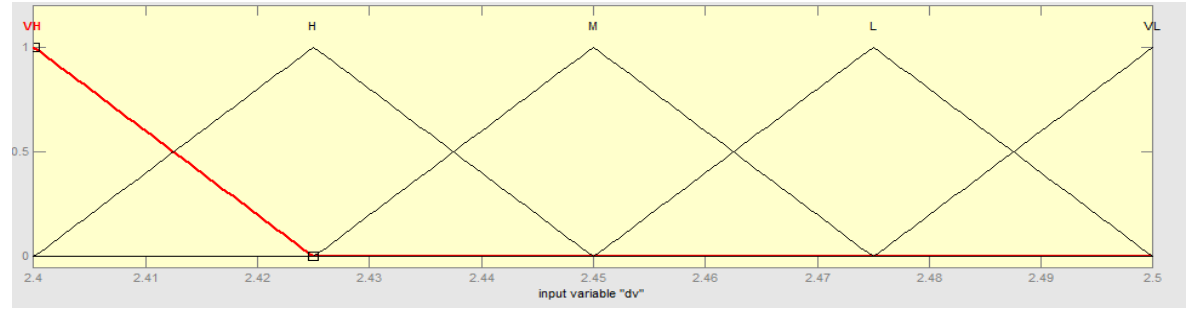

Fig.6.Input $(d V p v)$ Membership function

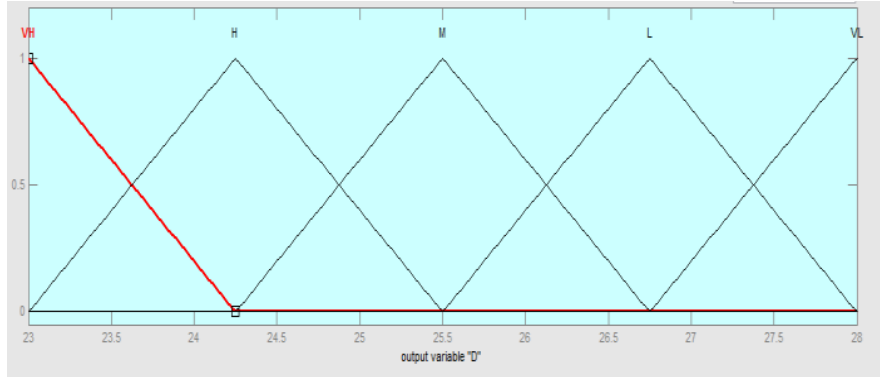

Fig.7.Output Dutycycle(D) Membership functions

\section{B) Inference method:}

The process of control output derived from the combination of input values, output values and membership functions and fuzzy element is called Inference method. Fuzzy rules are designed in the inference block of FLC.The rules implemented for proposed controller is as shown in Table III.

Table III. Proposed Fuzzy Rule

\begin{tabular}{|l|c|c|c|c|c|}
\hline Ppv & VH & H & M & L & VL \\
\hline VH & VH & VH & VH & H & M \\
\hline H & VH & H & H & M & L \\
\hline M & VH & H & M & L & L \\
\hline L & H & M & L & VL & VL \\
\hline VL & M & L & VL & VL & VL \\
\hline
\end{tabular}

\section{C) De-fuzzification Interface}

The converting fuzzy variables back into crisp variables are called Fuzzification. Fuzzy controller output is still a linguistic variable, and need to be converted to the crisp variable through a defuzzification process. The most commonly used method is centred method, which is based on the Eq. (11).

$$
D=\frac{\sum_{\mathrm{j}=1}^{\mathrm{N}} \mu(\mathrm{Mj})-(\mathrm{Mj})}{\sum_{\mathrm{j}=1}^{\mathrm{N}}(\mathrm{Mj})}
$$

The fuzzy rules developed for MPPT FLC is illustrated in fig8 

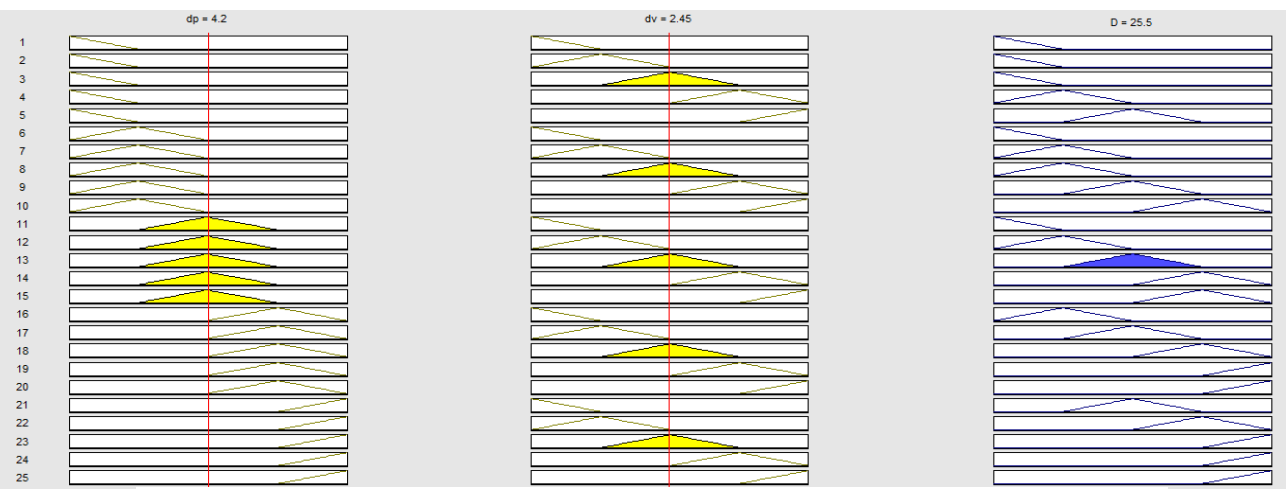

Fig.8. Rule viewer of Fuzzy interface system (five membership functions)

\section{Simulation Results And Discussion}

The DC-DC Boost converter and SEPIC Converter with PV system is modelled and simulated in MATLAB using Fuzzy logic Controller. The implemented simulation results are shown in Fig. (09) and Fig. (10) For SEPIC Converter at $1000 \mathrm{~W} / \mathrm{m}^{2}$ and $800 \mathrm{~W} / \mathrm{m}^{2}$ respectively.

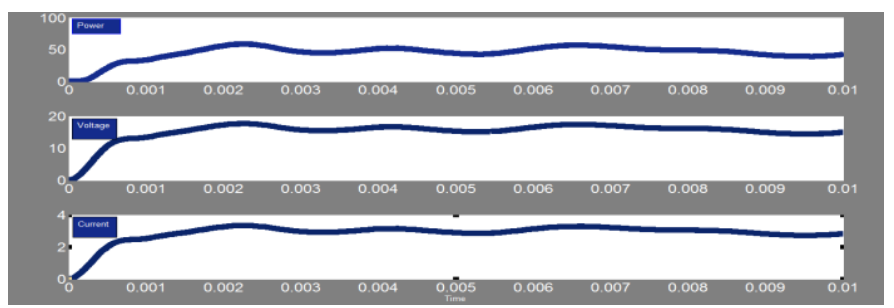

Fig.9. Power, Voltage, and Current of SEPIC Converter using FLC MPPT at 1000W/M2 and $25^{\circ} c$.

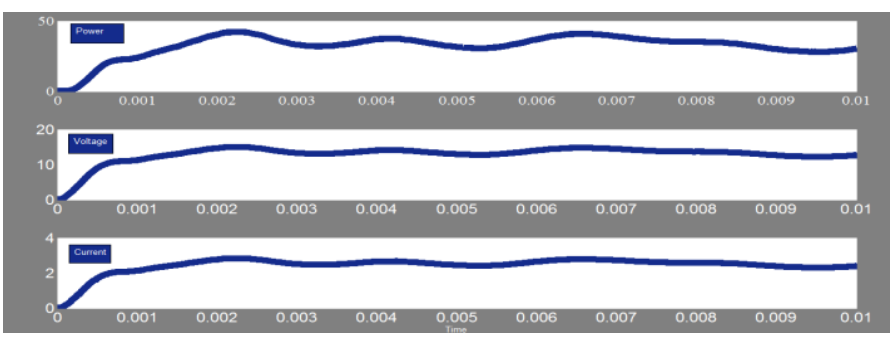

Fig.10.Power, Voltage and Current of SEPIC Converter using FLC MPPT at $800 \mathrm{~W} / \mathrm{M} 2$ and $25^{\circ} \mathrm{c}$

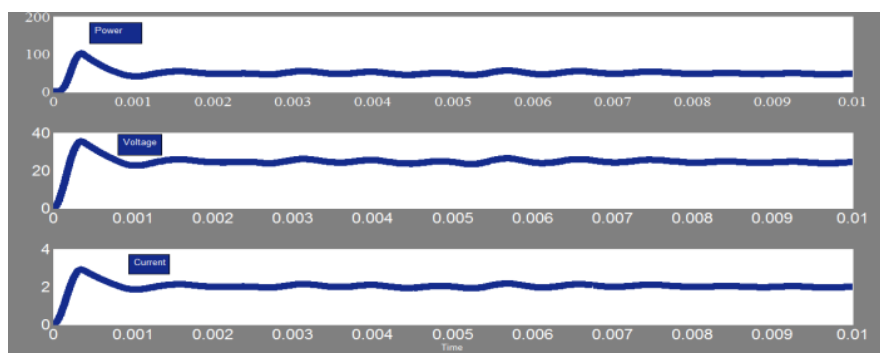

Fig.11. Power, Voltage and Current of Boost Converter using FLC MPPT at 1000W/M2 and $25^{\circ} c$.

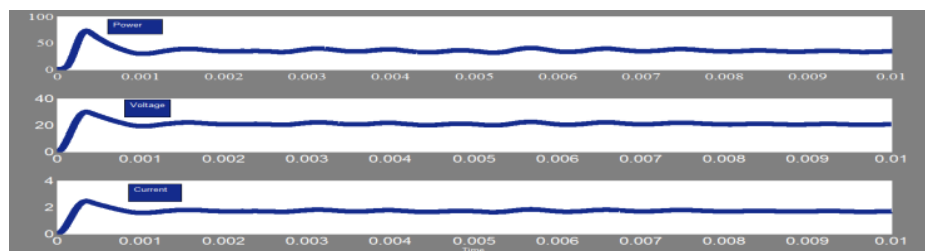

Fig.12. Power,Voltage and Current of Boost Converter using FLC MPPT at $800 \mathrm{~W} / \mathrm{M} 2$ and $25^{\circ} \mathrm{c}$.

The results obtained from simulation are shown in fig (11) and fig (12) for Boost Converter at 1000W/ $\mathrm{m}^{2}$ and $800 \mathrm{~W} / \mathrm{m}^{2}$ respectively.From fig (09), (10), (11) and (12), it is observed that maximum Power extracted 
from PV using FLC MPPT is more compared to SEPIC Converter at different irradiation and Constant temperature.

The Simulation results obtained for FLC based MPP is summarized in Table IV.

Table IV. Output Power Comparison of Boost and SEPIC Converter under different irradiation condition

\begin{tabular}{|c|c|c|}
\hline Irradiance $\mathrm{W} / \mathrm{M}^{2}$ & $\begin{array}{l}\text { Boost Converter Output } \\
\text { Power(W) }\end{array}$ & $\begin{array}{l}\text { SEPIC Converter } \\
\text { Output Power(W) }\end{array}$ \\
\hline 1000 & 48.49 & 42.34 \\
\hline 800 & 34.86 & 30.22 \\
\hline 600 & 19.62 & 16.74 \\
\hline 400 & 8.30 & 6.837 \\
\hline 200 & 1.761 & 1.283 \\
\hline
\end{tabular}

From the simulation results presented in Fig (9), (10), (11),(12) and table IV , it can be conclude that the Boost Converter is efficient topology for MPPT with FLC compared to SEPIC Converter.

\section{Conclusion}

A FLC MPPT method is implemented to extract maximum power in a PV System. The performance of FLC MPPT is validated with a Boost and SEPIC Converter for lamp load. Output Power comparison is made between Boost and SEPIC converter at different irradiation. It can be concluded that the efficiency of FLC MPPT with Boost converter is better compared to SEPIC Converter under different irradiation conditions.

\section{References}

[1]. J.A. Ramos, I. Zamora, J.J. Campayo. "Modeling of Photovoltaic Module", International Conference on Renewable Energies and Power Quality (ICREPQ'10) Granada, Spain, 23-25 March 2010

[2]. Chen Y, Smedley K M. A cost-effective single-stage inverter with maximum power point tracking [J].IEEE trans. Power Electron, 2004, 19(5):1289-1294.

[3]. J. E. Salazar-Duque, E. I. Ortiz-Rivera, and J. Gonzalez-Llorente, "Analysis and non-linear control of sepic dc-dc converter in photovoltaic systems," in Power Electronics and Power Quality Applications (PEPQA), 2015 IEEE Workshop on, 2015 , pp. 1-6.

[4]. A. Kavitha, G. Indira, and G. Uma, "Analysis and control of chaos in sepic dc-dc converter using sliding mode control," in Industry Applications Society Annual Meeting, 2008. IAS '08. IEEE, Oct 2008, pp. 1-6.

[5]. J. E. Salazar-Duque, E. I. Ortiz-Rivera, and J. Gonzalez-Llorente, "Analysis and non-linear control of sepic dc-dc converter in photovoltaic systems," in Power Electronics and Power Quality Applications (PEPQA), 2015 IEEE Workshop on, 2015, pp. 1-6.

[6]. D.Vijaya Bandhavi and S.R.Thilaga, "Fuzzy Based Hill-Climbing Method for Maximum Power Point in Microgrid Standalone Photovoltaic System", International Journal of Communications and Engineering Volume 03- No.3, Issue: 04 March2012

[7]. Basil M. Hamed and Mohammed S. El-Moghany, "Fuzzy Controller Design Using FPGA for Photovoltaic Maximum Power Point Tracking", 